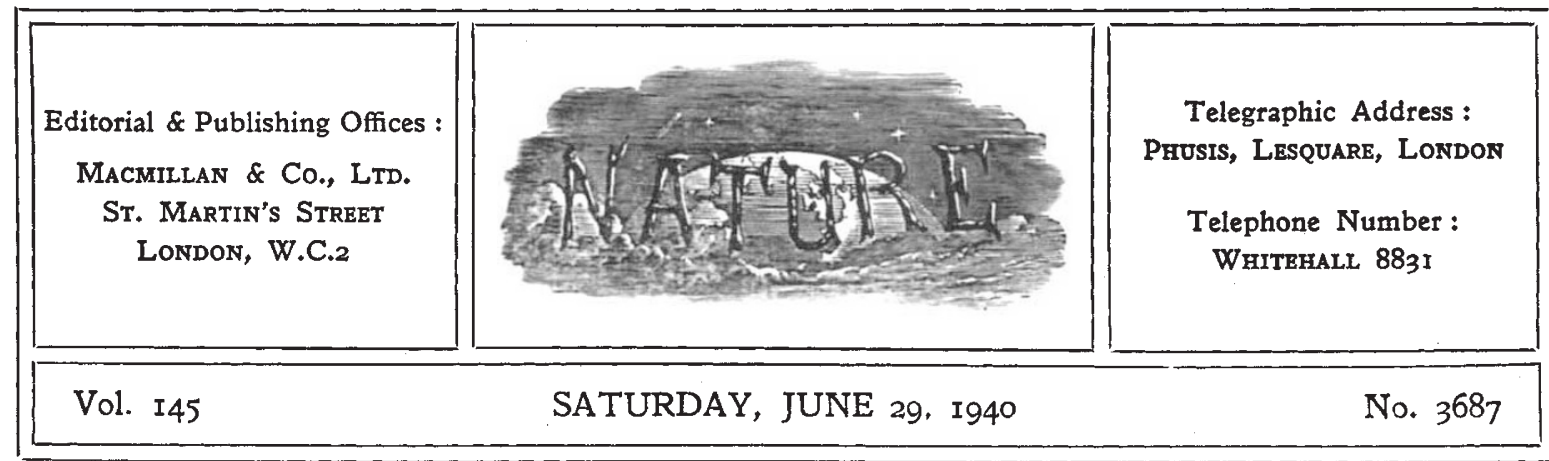

\title{
THE RANKS OF LIBERTY
}

$\mathrm{T}$ HE ranks of liberty have suddenly been thinned; physically they are weaker, but the blow has made them spiritually stronger. The action of the present French Government at Bordeaux has without doubt resulted in the capitulation of the mother country of the French Empire; what line of action will be followed by her Empire over-seas remains to be seen.

No one can lay a finger on a specific reason for this catastrophe; though the causes leading up to it have been manifold. It would be useless to close our eyes to the fact that one of the major causes has been-science. As the Prime Minister pointed out in the House of Commons on June 18, if we fail, the world will sink into the abyss of a new Dark Age, "made more sinister and perhaps more prolonged by the lights of a perverted science".

When the history of the present time, and especially of the period leading up to it, comes to be written, blame will be, rightly or wrongly, apportioned. Men of science have often heard their calling castigated for the use to which it is put in making mass murder, torture, bad faith and even treachery so easy as it is to-day. So, when the time comes, men of science will receive their portion, probably in excess, of the blame usually meted out by superficial thinkers. As we pointed out in NatuRE of June 15, p. 910 : "the conscience of science is clear. She offers man a rope to skip : she cannot be blamed if he chooses to hang himself with it." Thus are we glad to note that the Prime Minister realizes that it is a "perverted" science which is being utilized to further Totalitarian aims. We claimed that "science is willing, nay eager, to assist [man] along the path of prosperity and happiness which she has helped to provide."
Alas, many of those in authority are still unable or reluctant to grasp the great importance of what science and scientific workers offer to the advancement of civilization.

Much has been said and written about the social relations and implications of science. Men of science were becoming more and more aware of the humanistic aspect of their work, and great efforts were being made to bring the blessings of science to the forefront. But little has been done to prevent the perversion of science. An all too clear object lesson is now before us; and when the question of reconstruction can be usefully considered, this aspect must receive its due measure of attention - and a very large one it must be.

Meanwhile there is much to be done at once. Our thoughts turn to our French colleagues in their present sufferings. At the moment their fate is not known. Many of them are undoubtedly remaining at their posts. What the future holds for them remains to be seen; if they are treated as the men of science of other occupied territories are being treated, they will be able to carry on their work in a modified form, regimented as regards hours, etc.- -not an ideal atmosphere for scientific work.

It is quite possible that some French scientific workers have reached Great Britain, and others may perchance follow. These are early days, and one cannot foretell how many or what type of scientific worker may succeed in obtaining sanctuary in Great Britain. But whoever comes must be given not only sanctuary, but also an opportunity to pursue his calling. Those whose work is of immediate importance to the war effort should be absorbed into the various Government research departments ; the others, surely, will not 
look in vain to our universities and other institutes of scientific research.

Over a period of several years, these centres of research have responded admirably to the call for aid from refugees from divers countries. Many such aliens have now been inevitably interned. Our French colleagues constitute a different category. Everything must be done to help them, though we fear that the terms imposed upon France will preclude most French men of science from leaving their country and continuing their work in that atmosphere of freedom which still prevails in Great Britain, and for which all British and all free French will continue to work and fight.

\section{SCIENCE AND THE WAR EFFORT}

GOON after the present Government took office, the Minister of Supply, Mr. Herbert Morrison, made a powerful appeal for intensification of effort in the production of munitions and other commodities, in the course of which he used a phrase, "Go to it", that has already become a slogan. He asked for speeding up of manufacturing processes, the over-riding of trade customs and the hard-won privileges of the trade unions, and in general the subordination of everyone and everything to the supreme task of winning the War. The military disaster in France has accentuated our need. From now on, Great Britain is the immediate target, and the need for munitions to replace losses in France, as well as to provide for the needs of the future, should require no emphasis.

The immediate demands of our war effort upon scientific workers and other technical experts are, of course, for the provision of the skilled work of control, in the testing of materials and products, and in the supervision of processes to ensure that the production of munitions of war, whether of explosives, guns, tanks, aeroplanes, war-chemicals or other products is smoothly, efficiently and safely maintained. This demands the continuous scrutiny of existing products and processes with the view of improving them and of replacing them by others superior to those used by the enemy.

All this, however, is only the first and possibly the least significant part of the contribution of science, great as are the demands it makes on the scientific worker for untiring accuracy, patience and skill. The nation's production of armaments must in some measure be related to the natural resources available. Unless the fullest possible use is made of these, we may be wasting our reserves of man power, of transport, or of foreign exchange.

It is difficult indeed to visualize the many ramifications here involved. The most effective utilization of coal, for example, affects not merely the manner of burning raw coal, its carbonization or conversion to coke or gas, or the generation of electric power. The by-product position has to be considered with reference to raw materials which it provides for explosives or other branches of chemical industry. Questions of atmospheric pollution and the like are also linked up with this question of efficient utilization of fuel, and it needs little imagination to visualize the reactions upon public health, problems of transport and the location of industry.

The importance of the scientific contribution is equally important in regard to questions of crop production. The decision as to which crops attention should be concentrated upon involves not merely an accurate knowledge of soil and climatic conditions, questions of shipping space, the interlocking of export policy and exchange reserves. It is linked up also with the whole policy of agriculture and food supply.

The importance of this latter question has been repeatedly stressed of late by Sir John Orr, Sir Daniel Hall, Mr. C. S. Orwin and others, who in the daily Press and elsewhere have stressed the necessity for a scientific policy of food production and directed attention anew to the valuable services rendered during the War of 1914-18 by the Food (War) Committee of the Royal Society. Their arguments have since been strongly endorsed in the Fourth Report of the Select Committee on National Expenditure, which expresses serious doubts as to whether sufficient use is being made of scientific research in regard to the wider issues in planning of food policy, such as the allocation of sugar or the planning on the basis of the fullest scientific study of a ration adequate in calories, etc., at a less cost in shipping and external currency than with the presènt normal form of diet. At present there is evidence that allocations of supplies are being made on the basis of a rough 